\title{
CONTRIBUTIONS ON THE DETERMINATION OF THE RELATIONSHIP AMONG GLOBALIZATION, SUSTAINABLE DEVELOPMENT AND ENERGY SECURITY
}

\author{
Mihai-Marcel NEAG \\ mmneag@yahoo.com \\ Elisabeta-Emilia HALMAGHI \\ emmahalmaghi@gmail.com \\ Petruţa CUCUIET (MÂŢU) \\ petrutamatu@yahoo.com \\ “NICOLAE BĂLCESCU” LAND FORCES ACADEMY, SIBIU, ROMANIA
}

\begin{abstract}
The integrated approach to current security issues requires the study of human society by adopting the principle of sustainability for policies to be developed and applied according to economic, social and environmental impacts. The internationalization of economies raises a number of requirements for the application of this principle not only in domestic policies but also in external cooperation relations. Sustainability is thus a catalyst for internal and external political decisions, economic actions and public opinion to promote both new structural, institutional reforms and changes in production and consumption behaviours. The energy resources have permanently and overwhelmingly influenced the evolution of human society and its economic development, representing both a reason for cooperation and confrontation and disputes among the actors of the international system, while also shaping the economy, security, foreign policy and states priorities.
\end{abstract}

\section{KEYWORDS: \\ Durability, sustainable development, energy security}

\section{Introduction}

We live in a time when competition between states, regions and even continents is mainly in the economic field, and the expansion of this competition will also influence security of access to energy resources. Security environment analysis prefigures new security architecture globally while redeploying the world into new spheres of influence based on ownership, control and access to energy resources. 
As a result of the growth of technology revolutions in recent years, the development of future sciences and the expansion of the informational environment, globalization has made notable progress, both in terms of human development and the emergence of new risks and threats, especially non-military which cross the national borders and requires, in particular, to combat them nonmilitary complex measures. Given that the globalization process influences the security environment and the security domains are determined and influenced by each other, we will deal with the main aspects of globalization, sustainable development and security, especially energy security, as energy potential can to be used as a force instrument in international relations, especially if it is doubled by a military potential.

The phenomenon of globalization has accelerated economic, technological, cultural and political integration, together with democratic governance, market economy and respect for human rights, economic dynamism, and the revolution of communications (Popa, 2005). The accentuation of globalization has also led to increased interdependence and interaction in the security field, which has beneficial effects in the area of increasing stability in the sphere of international relations. Globalization shapes and propagates the issues of the new international security environment by addressing the most diverse aspects of sustainable development.

Sustainable development is a strategy that brings benefits from all the involved areas, efforts to develop what is important to achieving harmony and continuity will benefit the quality of life. From this perspective, the effort of the communities must be oriented towards solving the environmental, social problems in order to ensure the sustainability of human existence. Solutions are sought for all the problems that have been generated by the consumer society, having in mind transforming this society into an interested one and of social benefits, not just economic ones.

In one way or another, the degree of energy security also connects with the military sphere, with the activity of foreign policy, with the economic, environment protection and the social security field. At the same time, ensuring energy security implies today, more than in the past, correlations with the political and military aspects of security as a whole. The state of energy security involves overcoming vulnerabilities, counteracting risks, dangers and threats to meeting individual needs, and citizens' welfare and security interests cannot be met without ensuring economic security and, implicitly, energy security.

Recent developments in the security environment are in line with global trends regarding its remodeling and attempts to increase the influence of power centers, but we appreciate that the struggle for resources can generate economic disturbances with unavoidable effects in the social environment and may be at the origin of future crises/conflicts.

\section{Globalization \\ 2. Security Under the Impact of}

The security environment is a reality represented by all the political, diplomatic, economic, social, cultural, military, ecological and informational processes, phenomena, domestic and international, which condition the level of protection of the individual, the community, the state, the region, the region etc, while promoting their own interests. Due to a multitude of random factors, the security environment requires a re-adaptation of the security analysis criteria, hence a number of features: fluidity, complexity and volatility. "The security environment is undergoing continuous transformation, which is mainly reflected in the deepening of interdependencies and unpredictability in the international relations system, and the difficulty of delimiting the risks and threats 
of classical asymmetric and hybrid threats" (Administraţia Prezidenţială, 2015).

"Economic, political and cultural globalization, which has directly stimulated competition for resources, puts new light on the relationship between the state, the economy, regional and international markets. Globalization therefore favours both competition/cooperation for power and the struggle for resources, transport routes and markets. The phenomenon of globalization has accelerated economic, technological, cultural and political integration, together with democratic governance, market economy, and respect for human rights, economic dynamism and the revolution of communications" (Popa, 2005).

At the same time, it has increased and amplified the complexity of economic relations and interdependencies between states, but also between national and global economies. The global, fast and massive exchange of goods and services, capital, human resources, ideas and information has evolved in the context of the development of global transport, logistics and IT systems, thus contributing to increased interdependence and interaction and on security field, with beneficial effects in the area of increasing stability in the sphere of international relations. Moreover, the globalization of sources of threat to international security imposed a globalization of institutions, mechanisms and instruments of action against them, although there are different views on security challenges: terrorism and weapons of mass destruction, on the one hand, poverty and underdevelopment, on the other. The threats of the modern world, which target both the strong and weakest states, in our view, remain: international terrorism, the proliferation of weapons of mass destruction, interethnic and interreligious conflicts, organized crime networks, environmental problems and dangerous deepening of development gaps between the two sides.
The analysis of the current national security-security global security has prompted governments and international organizations to realize that preventing and managing conflicts and crises, controlling, maintaining and enforcing peace are no longer possible without the combined involvement of all security actors, from the biggest to the smallest. Globalization shapes and propagates the problems of the new international security environment, it can create a more prosperous world but can only be achieved if security is achieved, reaching the most diverse aspects of sustainable development.

\section{Sustainable Development Integrated into the Security System}

Sustainable development takes care of what it means to ensure the development of human activity, based on the resources of the environment, which in turn requires protection and restoration. The desires of sustainable development consist of concerted action in the economic, social and environmental spheres. Development is sustainable when it is based on both economic and social and environmental objectives. "Sustainable development is the development process that responds to current needs without endangering the ability of future generations to meet their own needs. [...] In order to achieve the goal of sustainable development, environmental protection will be an integral part of the process development and cannot be addressed independently” (D@dalos.org., 2017).

In the theoretical delimitation of the concept of sustainable development, we consider that the minimum requirements for the application of the concept include the following: resizing economic growth (account will be taken of the fair distribution of resources and the enhancement of the qualitative sides of production); eliminating poverty while meeting the essential needs for jobs, food, energy, water, housing and health; ensure population growth to an acceptable level 
(controlled demographic growth); conserving and enhancing natural resources, while monitoring the impact of economic activity on the environment; technology reorientation and risk control; decentralization of the forms of government, increased participation in decision-making; combining environmental and developmental decisions at the national level with international ones. Sustainable development is today an interdisciplinary concept that involves at least three elements in a close relationship of interdependence: economic programmes, programmes and measures to protect the environment and security.

The concept of sustainable development has become extremely important in politics all over the world. This development can be understood as a hope for environmental policy because an integral consideration of economic and social issues makes visible the broader context in which these environmental issues must transcend if we want to find an appropriate and acceptable solution from social view. The most necessary are economic, social and political changes (D@dalos.org., 2017). This means that socio-political actors have to take a special responsibility with regard to the political imposition of sustainability, which entails structural, institutional and financial consequences.

The concept of sustainable development pays special attention to placing human beings at the center of priorities. For developing countries there can be no preference between economic growth and environmental protection. Growth is not an option but an imperative. The problem is not how big the economic growth is, but "what kind of growth". On the other hand, countries with potentially developed financial, economic, human and technological potential have multiple chances to develop sustainable development. At the same time, from a certain threshold of environmental supportability, the issue of survival is the same for the entire planet, which determines the need for globalization of sustainable development actions.

Supporting the sustainable development of the economy and the achievement of strategic defence objectives requires the development of a network of physical, specialized and efficient infrastructures that mainly provide enhanced facilities and capabilities through:

- maintaining in the operating parameters and capitalizing the existing capacities through the rehabilitation and modernization of the civil and military infrastructures;

- rehabilitation, modernization and development of transport infrastructure, especially air and maritime;

- the realization of a modern, viable and secure communication infrastructure able to be integrated into the European communication system;

- developing the transport system of energy resources;

- promoting environmentally friendly transport technologies.

\section{Energy Security - Component of Economic Security}

The economic dimension of security is the ability of a state to accede constantly, securely and unencumbered to the resources and infrastructure needed for economic development. An economically strong state determines to a great extent the military force of the state. Also obtaining economic security can also generate conflicts, because a state's economic security state can cause a state of insecurity for another state.

Economic development, and implicitly economic security, is dependent on the natural resources that allow the world's states to fully or to a significant extent meet their consumption needs. Economic security thus becomes a component of national security and resides in a state of the economy, manifested through legality, balance and development. The aspect of the need to ensure uninterrupted supply of 
energy is a priority of economic security, but also an issue of energy security. Closer to economic security is energy security. Practically, energy security is an important, if not essential, component of economic security.

The uneven distribution of energy reserves, concentrated in certain geographic areas, results in the dependence of other geographic areas on their importation from surplus areas, which leads to a fierce competition for access to resources. Accessing or losing access to these resources can have unpredictable consequences, from economic instability with incalculable internal effects to changes in international hierarchies, phenomena that would practically destabilize the world. The whole debate and issue of energy security or the battle for current and probably future energy is only a consequence of the omnipresence of governments in the exploitation and control of natural resources, and the problem of energy resource depletion dominates the agendas of world stage actors.

Energy security is a concept with a complex interpretation due to factors that influence its understanding, and we are talking about competition for energy resources, changes and challenges in the natural environment, disputes over property rights over resources, and growing political instability and crises in the region of big energy producers. At the same time, energy security refers, on the one hand, to the achievement of a stable, fluid and sustainable energy market with reserves for the continuity of energy supply for the benefit of the citizens and the economy, together with the expansion of the use of alternative energy sources, and on the other hand, to physical security, the protection and guarding of energy infrastructure objectives, against terrorist acts.

Natural resources, especially energy, have permanently and overwhelmingly influenced the evolution of human society, economic development, national economies, the world economy, and, more recently, the global economy. In fact, in the 1970s, Henry Kissinger said, "control oil and control all continents" (Băhnăreanu, 2007). Michael Collon then claimed, "If you want to lead the world, you have to control oil, all oil. Wherever it is" (Băhnăreanu, 2007). Manifestation of power in the current security environment is not only done in terms of military force, but will depend, in particular, on the economic, technological and informational potential, on the access to the resources needed for a prosperous and sustainable development. The center of gravity of disputes and preemptive competitions has shifted from the military sphere to the economic sphere and takes place on geopolitical spaces, and the remodeling of the local, regional and global security environment is heavily dependent on energy resources.

The instability of energy security can seriously damage economic security, environmental security and social security, and implicitly political and military security. In the economic circuit, prices and diversity of supply sources are critical components of energy security. A distinct place in the relationship between the producer and the consumer begins to occupy the intermediary, ie the state through whose territory the energy vector transits. The intermediary seeks to consolidate the economic advantages offered by transit, but at the same time to devote its advantages to the political system of international relations (Băhnăreanu, 2008).

The impact and perception of energy security risks vary from one country to another. Oil and gas prices are fluctuating, impacting on global economies in general and on developing economies in particular. The short-term increase in oil and gas prices is a major threat to energy security for many developing countries where about one and a half billion people do not have access to electricity, and consumer expectations for energy services are often low. Half a billion people rely solely on 
biomass for cooking and heating fuels. Access to energy and environmental sustainability are inextricably linked because without access to energy sources and unsustainable exploitation of indigenous energy sources often lead to environmental degradation (Ölz, Sims and Kirchner, 2007). Access to energy is necessary before discussing security of energy supply.

For the first time, the actions foreseen in Agenda 2030 for Sustainable Development, elaborated at the UN Summit in September 2015, are equally targeted for developed and developing countries. Out of the 17 established Sustainable Development Goals (SDG), unofficially reunified under the heading of Global Objectives, 7 - Clean and Affordable Energy - Ensuring everyone's access to energy at affordable, safe, sustainable and modern (MFA, February 2016), all countries are envisaged equally.

So we can conclude that the state of energy security is defined by the following vectors: security of energy sources, securing existing energy routes, identifying alternative energy routes, identifying alternative energy sources, securing energy markets. At national level, the objective of ensuring energy security as a strategic objective is to bring about positive effects through: access to the energy resources necessary to operate at normal parameters of society in all aspects (economic, social and environmental welfare of citizens and firms); Greater predictability in terms of internal and external developments in the field; Good management of energy resources; Providing the most appropriate solutions at affordable cost (MAE, 2017).

\section{Conclusions}

Globalization processes must have the ultimate goal of sustainable development, just as securing a nation is through sustainable development. Globalization compresses space, often contrasted with different historical times, generated by distinct cultures and civilizations that have specific representations of the world and nature. For these reasons, understanding the globalization processes and accepting global solutions turns out to be a process of great complexity and difficulty.

Adopting the principle of sustainability requires that all policies be developed and applied according to their economic, social and environmental impacts, with the lowest and, above all, non-polluting costs. The internationalization of economies raises a number of requirements for the application of this principle not only in domestic policies but also in external cooperation relations. Trinomial economic globalization - the natural environment - the security environment determines the basic equations of the problem of the becoming of mankind, a phenomenon that can only be achieved through the models of sustainable development.

Sustainable development is a guarantee of the stability and security of the entire planet, countries, areas, regions, including the European continent. There can be no security without development, and development without sustainability cannot be a stable and stable construction in time and space.

Energy security means safe energy, in sufficient quantity and at affordable prices, becoming a constant concern for the international community. The link between ownership, demand, supply and use of energy resources, geographical spread and access to them, on the one hand, and security issues, on the other hand, is obvious. The control of classical energy resources has become a priority objective not only for the major actors of the world stage, but also for the new emerging powers and the various regional or international organizations. "Energy is essential to economic and social development and to improving the quality of life," the UN said in Agenda 21 of 1992.

Energy security is at the crossroads of all dimensions of security as its realization 
depends on reaching a certain degree of political and military consensus has a direct impact on the economy, society and the environment, and last but not least, it aims to protect every human being. Energy security is closely linked to the vulnerability to interruptions in the supply of energy resources (oil, gas, coal and electricity). The causes can be found in the following factors: armed conflicts, terrorism, natural disasters, political decisions, and geopolitical bipolar rivalries. Energy security must therefore take account of the challenges posed by the globalization process, any disruption or vulnerability in a part of the world, an energy source, can affect consumers around the world.

So, economic development, individual security, political stability, and sufficient and secure supply of energy are precondition for achieving security. Reflections on the correlation between globalization, sustainable development and energy security are moving from concept to policy, they must be found in major strategies, programmes and operational plans, in measures and actions aimed at allocating the necessary resources, and finally the fulfillment of the proposed security objectives.

\section{REFERENCES}

Administraţia Prezidenţială. (2015). Strategia naţională de apărare a ţării pentru perioada 2015-2019. O Românie puternică în Europa şi în lume, Bucureşti.

Băhnăreanu, C. (2008). Arma energetică în contextul relaţiilor internaţionale ale inceputului de secol XXI, Bucureşti: Editura Universităţii Naţionale de Apărare "Carol I".

Băhnăreanu, C. (2008). Securitatea energetică, Bucureşti: Editura Universităţii Naţionale de Apărare "Carol I".

D@dalos.org. (2017). Declaraţia asupra mediului şi dezvoltării, available at: http://www.dadalos.org/rom/menschenrechte/grundkurs 2/Materialien/dokument 9.htm.

Ministerul Afacerilor Externe. (2017). Securitate energetică, available at: https://www.mae.ro/node/1602.

Ölz S., Sims R. and Kirchner, N. (2007). Contribution of renewables to energy security, available at https://www.iea.org/publications/freepublications/publication/so contribution.pdf.

Popa, V. (2005) Implicaţiile globalizării asupra securităţii naţionale, Bucureşti: Editura Universităţii Naţionale de Apărare "Carol I".

United Nations. (1992). United nations conference on environment \& development, available at: https://sustainabledevelopment.un.org/content/documents/agenda21.pdf. 